JAMP: Jurnal Adminitrasi dan Manajemen Pendidikan Volume 2 Nomor 3 September 2019, Hal : 136-146

Tersedia Online di http://journal2.um.ac.id/index.php/jamp/ ISSN 2615-8574 (online)



JURNAL ADMINISTRASI DAN MANAJEMEN PENDIDIKAN

\title{
MANAJEMEN KEGIATAN EKSTRAKURIKULER SAINS CLUB UNTUK MENUNJANG KEAKTIFAN PESERTA DIDIK DALAM PEMBELAJARAN SCIENCE
}

\author{
Mery Dwi Rohmawati \\ Mustiningsih \\ Djum Djum Noor Benty \\ Universitas Negeri Malang - Jalan Semarang No.5 Malang \\ Email: merydwi.r@gmail.com
}

\begin{abstract}
The purpose of this study was to describe in detail the activities of management of science club extracurricular activities start from planning, organize, implementation, evaluation, inhibitor factors, support factors, and efforts in overcome barriers in club science extracurricular activities to support students' active learning science. This research was conducted through a qualitative approach using a type of case study to obtain descriptive data in a natural, comprehensive, and intensive manner. Data collection techniques were carried out through interviews, observation and documentation. The results of this study explained the activities of planning, organize, implementation, evaluation, inhibitor factors, support factors, and efforts in overcome barriers to extracurricular activities of club science to support the activity of students in learning science at Elementary School of My Little Island.
\end{abstract}

Keyword: management of extracurricular activities, club science, activeness of students

\begin{abstract}
Abstrak: Tujuan dari penelitian ini untuk mendeskripsikan secara rinci kegiatan dari manajemen kegiatan ekstrakurikuler sains club yang dimulai dari tahap perencanaan, pengorganisasian, pelaksanaan, penilaian, faktor penghambat, faktor penunjang, serta upaya dalam menanggulangi hambatan dalam kegiatan ekstrakurikuler sains club untuk menunjang keaktifan peserta didik dalam pembelajaran science. Penelitian ini dilakukan melalui pendekatan kualitatif dengan menggunakan jenis penelitian studi kasus untuk memperoleh data deskriptif secara alamiah, komprehensif, dan intensif. Teknik pengumpulan data dilakukan melalui wawancara, observasi dan dokumentasi. Hasil penelitian ini menjelaskan mengenai kegiatan perencanaan, pengorganisasian, pelaksanaan, penilaian, faktor penghambat, faktor pendukung, dan upaya menanggulangi hambatan kegiatan ekstrakurikuler sains club untuk menunjang keaktifan peserta didik dalam pembelajaran science di SD My Little Island.
\end{abstract}

Kata Kunci: manajemen kegiatan ekstrakurikuler, sains club, keaktifan peserta didik

Pengembangan potensi peserta didik secara maksimal menjadi tanggungjawab sekolah (Juharyanto, 2017a, 2017b). Salah satu upayanya, dilakukan melalui kegiatan ekstrakurikuler. Kepala sekolah memegang peran penting dan utama dalam mewujudkan capaian potensi maksimal peserta didik (Arifin,dkk., 2018), melalui ekstrakurikuler. Manajemen kegiatan ekstrakurikuler adalah serangkaian proses yang telah direncanakan dan diusahakan dapat terorganisasi dengan baik untuk mengatur kegiatan yang berada di luar jam pelajaran (kurikulum) yang bertujuan mengembangkan potensi dan keaktifan yang dimiliki oleh peserta didik.

Kegiatan ekstrakurikuler adalah program pendidikan yang alokasi waktunya tidak ditetapkan dalam kurikulum. Kegiatan ekstrakurikuler merupakan perangkat operasional (supplement dan complements) kurikulum, yang perlu disusun dan dituangkan dalam rencana kerja tahunan/kalender pendidikan satuan 
pendidikan. Kegiatan ekstrakurikuler digunakan untuk memenuhi kebutuhan dan perkembangan peserta didik yang berbeda. Melalui partisipasinya dalam kegiatan ekstrakurikuler peserta didik dapat belajar dan mengembangkan kemampuan berkomunikasi, bekerjasama dengan orang lain, serta menemukan dan mengembangkan potensinya (Damanik, 2014).

Kegiatan ekstrakurikuler dapat memberikan manfaat sosial yang sangat besar, karena dalam kegiatan ini peserta didik akan melakukan interaksi sosial dengan orang lain dan lingkungannya. Hal ini bertujuan untuk membentuk peserta didik agar dapat dipersiapkan turun langsung dalam lingkungan masyarakat. Dalam sekolah yang menerapkan kegiatan ekstrakurikuler, terdapat pula manajemen yang mengatur seluruh kegiatannya yang biasa disebut dengan manajemen ekstrakurikuler. Mulyono (dalam Kompri, 2015) menjelaskan bahwa pengelolaan kegiatan ekstrakurikuler merupakan keseluruhan kegiatan yang direncanakan dan diusahakan secara terorganisasi mengenai kegiatan yang dilakukan di luar kelas dan di luar jam pelajaran untuk mengembangkan potensi yang dimiliki siswa.

Potensi yang dimiliki peserta didik di sekolah dapat dikembangkan atau diwujudkan dengan kegiatan ekstrakurikuler. Hal ini sesuai dengan Peraturan Menteri Pendidikan dan Kebudayaan Nomor 81 A Tahun 2013 Tentang Implementasi Kurikulum yang menyatakan bahwa kegiatan ekstrakurikuler merupakan salah satu kegiatan yang diimplementasikan dalam program kurikuler. Kurikulum tidak menetapkan alokasi waktu untuk setiap kegiatan dalam ekstrakurikuler. Program ekstrakurikuler merupakan kegiatan yang dikembangkan oleh sekolah untuk dapat mengembangkan setiap potensi yang dimiliki oleh peserta didik. Kegiatan ekstrakurikuler diatur oleh sekolah menyesuaikan dengan jam belajar peserta didik. Hal ini sesuai dengan pendapat dari Zulkarnain (2015) yang menjelaskan bahwa kegiatan dalam ekstrakurikuler telah ditetapkan dalam kurikulum untuk pengalokasian waktu. Pembelajaran di kelas yang berbentuk mata pelajaran atau bidang studi dinamakan dengan kegiatan kurikuler. Namun, untuk kegiatan diluar jam belajar yang ditujukan sebagai wadah peserta didik dalam mengembangkan bakat dan minat yang dimiliki dinamakan dengan kegiatan ekstrakurikuler. Dengan kata lain, kegiatan yang dilakukan dalam rangka mengembangkan aspek-aspek tertentu dari yang ditemukan dalam mata pelajaran yang sedang dijalankan, termasuk yang berhubungan dengan bagaimana penerapan sesungguhnya dari ilmu pengetahuan yang dipelajari oleh peserta didik sesuai dengan kebutuhan hidupnya.

Pengelolaan yang sering disebut dengan manajemen kegiatan ekstrakurikuler. Mulyanto (dalam Kompri, 2015: 238) menjelaskan bahwa pengelolaan dalam kegiatan ekstrakurikuler merupakan seluruh proses yang direncanakan dan diusahakan secara terorganisir mengenai kegiatan sekolah yang dilakukan di luar kelas dan di luar jam pelajaran untuk mengembangkan potensi dan keterampilan yang dimiliki oleh peserta didik, baik dalam segi ilmu pengetahuan yang didapatkan ataupun untuk pengembangan bakat yang dimiliki. Menurut Machali (dalam Apriliyandari, 2015) menjelaskan bahwa sumber daya dalam manajemen yang perlu diperhatikan yaitu, manusia, uang, bahan/ alat-alat, teknik, mesin, pasar, dan waktu. Tanpa pelaksanaan dan pengelolaan hal-hal tersebut pendidikan hanya akan sia-sia karena akan menjadi pendidikan dengan kualitas yang rendah. Manajemen kegiatan ekstrakurikuler meliputi kegiatan perencanaan, pengorganisasian, pelaksanaan, dan penilaian.

Sains atau yang biasa dikenal dengan Ilmu Pengetahuan Alam menurut Sumaji (2009) memiliki upaya membangkitkan minat manusia agar mau meningkatkan kecerdasan dan pemahamannya tentang alam seisinya yang terkadang belum diketahui oleh kebanyakan orang. Perkembangan yang semakin pesat, membuktikan bahwa teknologi juga memiliki peran dalam kegiatan yang berinteraksi langsung dengan lingkungan, hal ini mengakibatkan kemampuan Sumber Daya Manusia (SDM) juga akan meningkat. Tingkat ilmu pengetahuan dan teknologi yang dicapai oleh suatu bangsa dapat dijadikan sebagai tolok ukur kemajuan dari bangsa tersebut.

Proses pembelajaran pada hakekatnya bertujuan untuk mengembangkan aktivitas dan kreativitas peserta didik melalui berbagai interaksi dan pengalaman belajar. Keaktifan belajar peserta didik merupakan unsur dasar yang penting bagi keberhasilan proses pembelajaran. Sudirman (2011) menjelaskan bahwa keaktifan merupakan kegiatan yang bersifat mental ataupun fisik, yaitu berfikir dan berbuat sebagai suatu rangkaian yang tidak dapat dipisahkan. Keaktifan yang dimaksud dalam proses 
pembelajaran adalah terjadinya dialog interaktif antara peserta didik dengan peserta didik, peserta didik dengan guru atau peserta didik dengan sumber belajar lainnya (Hamzah dan Nurdin, 2012). Jadi keaktifan belajar adalah suatu kegiatan dimana peserta didik aktif dalam pembelajaran. Keaktifan belajar dapat dilihat dari keterlibatan peserta didik dalam proses belajar mengajar yang beraneka ragam seperti mendengarkan penjelasan guru, diskusi, membuat laporan pelaksanaan tugas.

SD My Little Island Kota Malang ini memiliki banyak kegiatan yang berhubungan dengan lingkungan, seperti melakukan percobaan, studi empiris eco green park, green school festival, belajar membuat kompos, yang sekarang lebih dikelola oleh kegiatan ekstrakurikuler yang bernama sains club. Berdasarkan studi pendahuluan yang dilakukan, peneliti melakukan wawancara dengan Bapak Majid selaku pembina kegiatan ekstrakurikuler sains club di SD My Little Island, dapat diperoleh informasi bahwa kegiatan ekstrakurikuler sains club ini berdiri sejak Tahun 2015. Kegiatan yang ada dalam ekstrakurikuler sudah disusun secara rinci oleh lembaga yang menaungi kegiatan ekstrakurikuler ini. Kegiatan yang ada didalamnya antara lain pengamatan, observasi, dan praktik. Praktik yang diberikan setiap pertemuan selalu berubah-ubah disesuaikan dengan jadwal yang telah disusun.

Manajemen kegiatan ekstrakurikuler di SD My Little Island dilaksanakan melalui kerjasama oleh pihak sekolah dengan lembaga bimbingan kegiatan ekstrakurikuler sains club yang bernama Lembaga Sains Cendikia. Perencanaan dalam kegiatan ini secara umum dilakukan oleh pihak lembaga yang kemudian dikonsultasikan dengan pihak sekolah.

\section{METODE}

Pendekatan yang digunakan dalam penelitian ini adalah pendekatan kualitatif dengan tujuan mendeskripsikan dan menggambarkan mengenai manajemen kegiatan ekstrakurikuler sains club. Pendekatan ini dipilih karena fokus dalam penelitian ini berkaitan dengan proses sehingga diperlukan pengamatan dan observasi. Jenis penelitian di SD My Little Island yang digunakan adalah studi kasus, yang memfokuskan sasaran pada kegiatan perencanaan, pengorganisasian, pelaksanaan, penilaian, faktor penghambat, faktor penunjang, dan upaya menanggulangi hambatan yang terjadi dalam kegiatan ekstrakurikuler sains club di SD My Little Island.

Prosedur pengumpulan data dalam penelitian ini didapatkan melalui kegiatan wawancara, observasi, dan dokumentasi. Peneliti membuat daftar pertanyaan atau yang dinamakan dengan instrumen sebagai panduan wawancara yang telah dipersiapkan sebelumnya sesuai dengan fokus penelitian. Metode wawancara digunakan oleh peneliti untuk mendapatkan informasi mengenai kegiatan perencanaan, pengorganisasian, pelaksanaan, penilaian, faktor penghambat, faktor penunjang, serta upaya untuk menanggulangi hambatan dari kegiatan ekstrakurikuler sains club di SD My Little Island. Kegiatan yang dilakukan oleh peneliti yaitu melakukan kesepakatan dengan narasumber untuk melakukan wawancara serta menentukan jadwal pelaksanaan wawancara. Hasil dari kegiatan wawancara ditulis oleh peneliti dalam bentuk transkip wawancara yang kemudian akan dilakukan member check serta penandatanganan transkip wawancara oleh narasumber.

Observasi yang dilakukan peneliti yaitu mengikuti berlangsungnya kegiatan ekstrakurikuler dari awal hingga akhir serta membantu pembina kegiatan ekstrakurikuler dalam mempersiapkan peralatan yang akan digunakan dalam pelaksanaan kegiatan. Selain itu, peneliti mengamati keterlibatan peserta didik dalam pelaksanaan kegiatan ekstrakurikuler dan ikut membantu peserta didik yang mengalami kesulitan. Peneliti mencatat hasil observasi yang dilaksanakan dalam bentuk catatan lapangan. Dokumentasi yang dilakukan peneliti yaitu dengan mengumpulkan foto dokumentasi kegiatan dan dokumen resmi berupa format penilaian kegiatan ekstrakurikuler sains club, jadwal kegiatan ekstrakurikuler sains club, penilaian kegiatan ekstrakurikuler sains club, daftar nama peserta kegiatan ekstrakurikuler sains club yang berkaitan dengan obyek pengamatan. 


\section{HASIL}

\section{Perencanaan Kegiatan Ekstrakurikuler Sains Club untuk Menunjang Keaktifan Peserta Didik dalam Pembelajaran Science di SD My Little Island}

Perencanaan kegiatan ekstrakurikuler sains club di SD My Little Island dilakukan setiap awal semester, hal ini dikarenakan setiap awal semester selalu diadakan perekrutan untuk anggota kegiatan ekstrakurikuler sains club. Kegiatan yang dilakukan dalam perencanaan meliputi penetapan tujuan kegiatan, penetapan indikator kegiatan, penyusunan program kegiatan, menentukan pihak-pihak yang terlibat atau berperan dalam kegiatan perencanaan baik dari Lembaga Sains Cendikia atau dari SD My Little Island, penyusunan alokasi dana untuk kegiatan ekstrakurikuler sains club, memenuhi sarana dan prasarana untuk pelaksanaan kegiatan, menetapkan tata tertib kegiatan, serta menentukan alokasi waktu untuk pelaksanaan kegiatan. Perencanaan harus dibuat sebaik dan sejelas mungkin untuk mengetahui alur dari suatu kegiatan, yang berperan dalam kegiatan perencanaan ini yaitu tim riset, ketua Lembaga Sains Cendikia, pembina kegiatan ekstrakurikuler, guru science, dan Wakil Kepala Bagian Kesiswaan.

\section{Pengorganisasian Kegiatan Ekstrakurikuler Sains Club untuk Menunjang Keaktifan Peserta Didik dalam Pembelajaran Science di SD My Little Island}

Pengorganisasian sangat dibutuhkan dalam manajemen kegiatan ekstrakurikuler sains club untuk mempermudah dalam mengetahui tugas, wewenang, dan tanggungjawab yang diemban dari setiap orang. Kegiatan ekstrakurikuler sains club di SD My Little Island melibatkan dua lembaga yaitu sekolah dengan Lembaga Sains Cendikia, jadi tugas, wewenang, dan tanggungjawab yang dimiliki juga berbeda. Pengorganisasian dalam kegiatan ekstrakurikuler sains club meliputi penyusunan struktur organisasi, penentuan waktu pembuatan struktur organisasi, dan pembagian tugas dan wewenang.

Pembagian tugas dan wewenang diletakkan paling akhir dari tahap ini dikarenakan, tugas dan wewenang yang akan diperoleh setiap orang didasarkan pada struktur organisasi yang telah disusun sebelumnya. Kegiatan ini dilakukan setelah penyusunan struktur organisasi. Tugas dan wewenang harus dapat disepakati bersama antara pihak yang terkait. Lembaga Sains Cendekia memiliki pembagian tugas dan wewenang yaitu bagian kekaryawanan dan keuangan itu jadi satu orang, kemudian ada bagian produksi dan gudang ada satu orang, tim riset. Tugas dari direkturnya sendiri itu mengawasi dari tim itu berjalan dengan lancar, kemudian proses untuk menyediakan cabang-cabang baru. Bagian manager bertugas untuk mengontrol aktivitas harian, bagian kepegawaian menyusun jadwal pengajar, mengatur sistem penggantinya, mengatur pembukaan lowongan pekerjaan, serta ada fasilitator yang bertugas untuk mengajar.

\section{Pelaksanaan Kegiatan Ekstrakurikuler Sains Club untuk Menunjang Keaktifan Peserta Didik dalam Pembelajaran Science di SD My Little Island}

Pelaksanaan kegiatan merupakan salah satu inti dari sebuah manajemen. Pelaksanaan kegiatan ekstrakurikuler sains club ini merupakan implementasi dari perencanaan program yang telah disusun. Pelaksanaan kegiatan ekstrakurikuler sains club di SD My Little Island meliputi kegiatan penyesuaian program dengan jadwal pelaksanaan, implementasi program kegiatan, peran serta sekolah dan Lembaga Sains Cendikia dalam pelaksanaan, meningkatkan antusiasme peserta didik dalam pelaksanaan kegiatan, serta meningkatkan keaktifan peserta didik. Kegiatan ekstrakurikuler sains club sangat erat kaitannya dengan keaktifan peserta didik, hal ini dikarenakan dalam kegiatan ini peserta didik dibebaskan untuk melakukan eksperimen baik secara individu maupun kelompok sehingga peserta didik lebih berani dalam mengemukakan pendapat, bertanya, membantu teman yang kesusahan, atau juga dengan melakukan diskusi dengan teman yang lain. 


\section{Penilaian Kegiatan Ekstrakurikuler Sains Club untuk Menunjang Keaktifan Peserta Didik dalam Pembelajaran Science di SD My Little Island}

Penilaian merupakan bagian akhir dari suatu manajemen. Penilaian berisi tentang pertanggungjawaban dari kegiatan perencanaan, pengorganisasian, dan pelaksanaan untuk kegiatan ekstrakurikuler sains club di SD My Little Island. Penilaian dalam kegiatan ini meliputi menyusun dan menentukan kriteria keberhasilan program, melakukan pengawasan terhadap kegiatan ekstrakurikuler sains club, melakukan penilaian kegiatan, membuat laporan hasil pengawasan, dan melakukan evaluasi. Penilaian sangat penting dilakukan untuk mengetahui tingkat keberhasilan dari suatu kegiatan yang telah diimplementasikan, serta untuk mengetahui peningkatan dari pengetahuan yang dimiliki oleh peserta didik setelah mengikuti kegiatan ekstrakurikuler sains club. Rubrik penlilaian dibuat oleh Lembaga Sains Cendikia dengan persetujuan dari sekolah, namun sekolah juga memiliki lembar penilaian untuk pelaksanaan kegiatan dan keaktifan peserta didik selama mengikuti kegiatan.

\section{Faktor Penghambat Pelaksanaan Kegiatan Ekstrakurikuler Sains Club untuk Menunjang Keaktifan Peserta Didik dalam Pembelajaran Science di SD My Little Island}

Pelaksanaan kegiatan ekstrakurikuler sains club tidak terlepas dengan adanya faktor penghambat. Faktor penghambat yang terdapat dalam kegiatan ekstrakurikuler sains club meliputi kurangnya tenaga pengajar, perbedaan karakteristik peserta didik, tidak ada ruang laboratorium IPA untuk melakukan eksperimen, pengubahan jadwal kegiatan, serta pengubahan program kegiatan yang diminta oleh sekolah dengan menyesuaikan pada kebutuhan dan keinginan yang akan dicapai oleh sekolah.

\section{Faktor Pendukung Pelaksanaan Kegiatan Ekstrakurikuler Sains Club untuk Menunjang Keaktifan Peserta Didik dalam Pembelajaran Science di SD My Little Island}

Faktor pendukung dari kegiatan ekstrakurikuler sains club di SD My Little Island sangat diperlukan, karena dengan adanya faktor pendukung kegiatan ini dapat terlaksana dengan baik. Faktor pendukung dari kegiatan ini meliputi penugasan guru sebagai penanggungjawab kegiatan di kelas, terpenuhinya sarana untuk melakukan eksperimen. Sarana yang dimaksud adalah alat dan bahan dalam melakukan suatu eksperimen, hal ini manjadi faktor pendukung karena semua alat dan bahan telah disiapkan oleh Lembaga Sains Cendikia.

\section{Upaya Mengatasi Hambatan Kegiatan Ekstrakurikuler Sains Club untuk Menunjang Keaktifan Peserta Didik dalam Pembelajaran Science di SD My Little Island}

Hambatan yang ada harus segera diselesaikan agar kegiatan dapat berlangsung dengan lancar. Terdapat beberapa upaya untuk mengatasi hambatan dalam kegiatan ekstrakurikuler ini meliputi, penugasan guru oleh sekolah untuk membantu dalam pelaksanaan, menyusun program sesuai dengan keinginan peserta didik agar kegiatan yang dilakukan dapat merata, memanfaatkan ruang kelas sebagai ruang praktik, pergeseran waktu pelaksanaan menjadi lebih cepat atau lambat agar tidak mengubah waktu dan program yang telah disusun, serta penyesuaian program dengan inovasi agar kegiatan tidak monoton dan membosankan.

\section{PEMBAHASAN}

\section{Perencanaan Kegiatan Ekstrakurikuler Sains Club untuk Meningkatkan Keaktifan Peserta Didik dalam Pembelajaran Science di SD My Little Island}

Penetapan strategi pelaksanaan, harus ditetapkan pula penanggungjawab dari keseluruhan program kegiatan ekstrakurikuler. Berdasarkan temuan dari peneliti dalam perencanaan kegiatan ekstrakurikuler sains club didapati pula penetapan alokasi dana kegiatan, pemenuhan sarana dan prasarana, dan alokasi waktu. Hal ini juga didukung dengan pendapat Zulkarnain (2015) yang menjelaskan bahwa dalam perencanaan kegiatan juga melakukan penyusunan rencana kegiatan ekstrakurikuler yaituwaktu, tempat, fasilitas, sumber, bahan, jaringan, tenaga, dan besarnya alokasi dana untuk kegiatan tersebut. 
Perencanaan dalam Kegiatan Ekstrakurikuler Sains Club sesuai dengan pendapat dari Zulkarnain (2015) meliputi; (a) sekolah menetapkan tujuan, jenis kegiatan, dan sasaran kegiatan; (b)melakukan seleksi terhadap potensi, bakat, minat, keinginan, dan kemampuan yang dimiliki oleh peserta didik sebagai bahan pertimbangan dalam penetapan kuota peserta dan jenis kegiatan; (c) pengelompokan peserta didik sesuai dengan kuota yang disediakan sesuai dengan bakat dan minat dari peserta didik; (d) melakukan penyusunan rencana kegiatan ekstrakurikuler yaitu waktu, tempat, fasilitas, sumber, bahan, jaringan, tenaga, dan besarnya alokasi dana untuk kegiatan. Sedangkan dari hasil temuan yang didapatkan oleh peneliti di SD My Little Island perencanaan untuk perencanaan kegiatan ekstrakurikuler sains club meliputi; (a) penetapan tujuan kegiatan; (b) penetapan indikator; (c) penyusunan program; (d) alokasi dana kegiatan; (e) pemenuhan sarana dan prasaran; (f) penetapan tata tertib kegiatan; dan (g) penetapan alokasi waktu. Terdapat perbedaan dari pendapat yang disampaikan oleh Zulkarnain (2015) dengan hasil temuan peneliti terletak pada dilakukannya seleksi terhadap potensi, bakat, minat, keinginan, dan kemampuan yang dimiliki oleh peserta didik. Hal ini dikarenakan sekolah memberikan kebebasan kepada peserta didik untuk memilih kegiatan ekstrakurikuler apa yang diinginkan, tugas dari sekolah hanya mengarahkan dan menyediakan sarana penyalur bakat dan minat peserta didik melalui kegiatan ekstrakurikuler yang telah disediakan. Pemilihan kegiatan ekstrakurikuler yang dilakukan di SD My Little Island tidak melalui tahap seleksi, namun ketika kuota yang telah ditetapkan sudah terpenuhi maka harus ada pengalihan pemilihan kegiatan ekstrakurikuler oleh peserta didik yang dibimbing langsung oleh pihak sekolah melalui Wakil Kepala Bagian Kesiswaan.

\section{Pengorganisasian Kegiatan Ekstrakurikuler Sains Club untuk Meningkatkan Keaktifan Peserta Didik dalam Pembelajaran Science di SD My Little Island}

Pengorganisasian sangat penting dilakukan untuk memperjelas tugas, wewenang, dan tanggungjawab dari pihak-pihak yang terlibat dalam Kegiatan Ekstrakurikuler Sains Club. Hasil temuan yang didapatkan oleh peneliti di SD My Little Island proses pengorganisasian meliputi; (a) pembuatan struktur organisasi; (b) waktu pembentukan struktur organisasi; dan (c) menentukan tugas dan wewenang. Sesuai dengan pedapat yang dijelaskan oleh Purwanto (2008) bahwa proses pengorganisasian merupakan aktivitas menyusun dan membentuk hubungan kerja antara orang-orang sehingga terwujud suatu kesatuan usaha dalam mencapai tujuan yang telah ditetapkan. Pengorganisasian ini yang dianggap paling penting adalah adanya pembagian tugas, wewenang, dan tanggungjawab yang disesuaikan dengan pengalaman, bakat, minat, pengetahuan, dan kepribadian. Berdasarkan temuan yang didapatkan oleh peneliti di SD My Little Island, struktur organisasi untuk Kegiatan Ekstrakurikuler Sains Club hanya ada di Lembaga Sains Cendikia karena sekolah melakukan kerjasama dalam melaksanakan kegiatan ekstrakurikuler sains club ini. Hal ini juga disampaikan oleh Zulkarnain (2015) bahwa sekolah yang tidak memiliki guru berlatarbelakang pendidikan yang relevan dan tidak berminat menyelenggarakan kegiatan ekstrakurikuler, dapat dengan cara mengundang guru atau instruktur di bidang ekstrakurikuler dari lembaga atau sekolah lain melalui kerjasama. Lembaga Sains Cendikia diharapkan dapat membantu efektifitas dalam pelaksanaan kegiatan ekstrakurikuler sains club di SD My Little Island karena secara organisasi telah tersusun dengan rinci mengenai tugas, wewenang, dan tanggungjawab yang diemban.

\section{Pelaksanaan Kegiatan Ekstrakurikuler Sains Club untuk Meningkatkan Keaktifan Peserta Didik dalam Pembelajaran Science di SD My Little Island}

Pelaksanaan kegiatan merupakan salah satu inti dari sebuah manajemen, karena pelaksanaan merupakan implementasi dari suatu kegiatan yang telah disusun dan direncanakan sebelumnya. Berdasarkan hasil temuan yang didapatkan oleh peneliti terdapat beberapa tahap dalam pelaksanaan kegiatan ekstrakurikuler sains club di SD My Little Island yang meliputi; (a) penyesuaian program dengan jadwal pelaksanaan; (b) implementasi program; (c) peran serta pihak sekolah dan lembaga dalam pelaksanaan; (d) peningkatan antusiasme peserta didik; (e) peningkatan keaktifan peserta didik. Sesuai dengan pendapat yang diungkapkan oleh Kompri (2015) yang menjelaskan bahwa penjadwalan waktu dalam kegiatan ekstrakurikuler harus dirancang pada awal tahun atau semester dengan dibimbing oleh kepala sekolah atau wakil kepala sekolah bagian kurikulum dan peserta didik. Selain itu terdapat pula pendapat dari Zulkarnain (2015) yang menyatakan bahwa dalam kegiatan ekstrakurikuler harus 
terdapat variasi antara sekolah dengan sekolah lain, serta harus mencapai tujuan yang telah ditetapkan. SD My Little Island melaksanakan kegiatan ekstrakurikuler sains club dengan tujuan melatih peserta didik untuk lebih mengenal lingkungan sekitar, menciptakan rasa toleransi, bekerjasama, serta memiliki keberanian dalam bertanya, menyampaikan pendapat, presentasi atau yang lebih dikenal dengan istilah keaktifan.

Pelaksanaan kegiatan ekstrakurikuler sains club dilihat dari beberapa hal menurut Sopiatin (dalam Zulkarnain, 2015) yang diterapkan di SD My Little Island adalah pelaksanaan kegiatan ekstrakurikuler dibina oleh petugas khusus sesuai dengan bidang dan keahlian dan bertanggungjawab kepada kepala sekolah, dan setiap peserta didik memiliki hak yang sama untuk mengikuti kegiatan ekstrakurikuler sesuai dengan potensi, minat, dan bakatnya masing-masing. Hal ini dianggap sesuai karena kegiatan ekstrakurikuler sains club di SD My Little Island dilakukan berdasarkan kerjasama yang dilakukan oleh sekolah dengan Lembaga Sains Cendikia. Peserta didik juga diberikan kebebasan dalam memilih kegiatan ekstrakurikuler apa yang ingin diikuti pada awal semester tanpa adanya paksaan atau tekanan dari pihak manapun.

Kegiatan ekstrakurikuler sains club di SD My Little Island sesuai dengan temuan yang diperoleh oleh peneliti yaitu meningkatkan antusiasme peserta didik serta meningkatkan keaktifan peserta didik. Sesuai dengan yang diungkapkan oleh Hamzah dan Nurdin (2012) bahwa keaktifan yang dimaksud yaitu proses pembelajaran adalah terjadinya dialog interaktif antara peserta didik degan peserta didik, peserta didik, peserta didik dengan guru atau peserta dengan sumber belajar lainnya. Keaktifan belajar yang dapat dilihat dari kegiatan ekstrakurikuler ini yaitu adanya keterlibatan peserta didik dalam proses belajar mengajar yang beraneka ragam seperti mendengarkan penjelasan guru, diskusi, membuat laporan dan mengerjakan tugas setelah pelaksanaan tugas. Hal tersebut juga dikuatkan dengan UndangUndang Republik Indonesia Nomor 20 Tahun 2003 Tentang Sistem Pendidikan Nasional, Bab II Pasal 3 yang menjelaskan bahwa pendidikan nasional berfungsi untuk mengembangkan kemampuan dan membentuk watak serta peradaban bangsa yang bermartabat dalam rangka mencerdaskan kehidupan bangsa, bertujuan untuk berkembangnya potensi peserta didik agar menjadi manusia yang beriman dan bertakwa kepada Tuhan Yang Maha Esa, berakhlak mulia, sehat, berilmu, cakap, kreatif, mandiri, dan menjadi warga negara yang demokratis serta bertanggungjawab.

\section{Penilaian Kegiatan Ekstrakurikuler Sains Club untuk Meningkatkan Keaktifan Peserta Didik dalam Pembelajaran Science di SD My Little Island}

Penilaian merupakan tahap akhir dari sebuah manajemen. Sebelum penilaian, maka akan diadakan evaluasi terlebih dahulu mengenai kegiatan yang telah dilaksanakan. Hasil temuan yang didapatkan oleh peneliti mengenai penilaian Kegiatan Ekstrakurikuler Sains Club di SD My Little Island terdapat beberapa tahap yaitu; (a) menyusun dan menentukan kriteria keberhasilan program; (b) melaksanakan penilaian; (c) melakukan pengawasan kegiatan; (d) pembuatan laporan pengawasan; (e) pelaksanaan evaluasi kegiatan. Sesuai dengan pendapat yang diungkapkan Kompri (2015) bahwa kegiatan penilaian yang dilakukan dalam kegiatan ekstrakurikuler ditujukan untuk mengumpulkan data atau informasi mengenai tingkat keberhasilan yang dicapai siswa. Penetapan tingkat keberhasilan peserta didik dilandaskan atas standar minimal yang telah ditetapkan dalam penguasaan kemampuan secara individual. Hal ini sesuai dengan Kegiatan Ekstrakurikuler Sains Club yang ada di SD My Little Island, karena keberhasilan dalam pelaksanaan program dapat dilihat dari kemampuan individu itu sendiri ketika menyelesaikan program dan mengerjakan lembar kuis yang telah tersedia di modul.

Penyusunan dan penentuan kriteria keberhasilan program harus dibuat diawal kegiatan karena sebagai acuan untuk mengetahui perkembangan dan keberhasilan dari program yang dilaksanakan. Hal ini sesuai dengan ungkapan Mustiningsih (2018) yang menjelaskan bahwa kriteria keberhasilan dalam kegiatan ekstrakurikuler meliputi proses pencapaian kompetensi yang didapatkan oleh peserta didik. Hal-hal yang digunakan sebagai standar penilaian mutu kegiatan ekstrakurikuler menurut Zulkarnain (2015) yang diterapkan dalam kegiatan ekstrakurikuler sains club di SD My Little Island adalah kegiatan ekstrakurikuler yang berhubungan langsung dengan materi pelajaran. Standar kualitas kegiatan ditentukan dari keteraturan dalam melaksanakan kegiatan, jumlah peserta didik yang mengikuti kegiatan, 
guru yang mempunyai kompetensi sesuai dengan materi yang diberikan, dan fasilitas yang disediakan. Kegiatan ini dipilih sebagai kegiatan ekstrakurikuler pilihan di SD My Little Island untuk menunjang pembelajaran science di kelas melalui metode eksperimen yang dapat membuat peserta didik lebih cepat ingat dan mampu menerapkan dalam kehidupan sehari-hari.

Untuk menindaklanjuti dari hasil penilaian yang dilakukan, sekolah harus membuat laporan secara rutin mengenai keseluruhan program kegiatan ekstrakurikuler dan untuk setiap jenis kegiatannya. Laporan yang disusun ini sangat membantu dalam melakukan pertanggungjawaban sekolah mengenai keuangan sekolah dan alokasi dana untuk kegiatan. Setelah pembuatan laporan, akan diadakan evaluasi kegiatan. Evaluasi kegiatan ini bertujuan untuk mengetahui keberhasilan dari kegiatan ekstrakurikuler sains club, dan mengetahui hambatan yang terjadi selama kegiatan berlangsung. Serta untuk menentukan acuan program kegiatan untuk semester selanjutnya. Seperti yang diungkapkan oleh Mustiningsih (2018) bahwa evaluasi kegiatan ekstrakurikuler dilakukan untuk mengukur ketercapaian tujuan pada setiap indikator yang telah ditetapkandalam perencanaan satuan pendidikan.

\section{Faktor Penghambat dalam Pelaksanaan Kegiatan Ekstrakurikuler Sains Club untuk Meningkatkan Keaktifan Peserta Didik dalam Pembelajaran Science di SD My Little Island}

Pelaksanaan kegiatan ekstrakurikuler sains club tidak terlepas dari hambatan-hambatan yang terjadi. Hasil temuan yang didapatkan oleh peneliti menyebutkan bahwa faktor penghambat yang terjadi dalam pelaksanaan kegiatan ini antara lain kurangnya tenaga pengajar, pengubahan waktu, dan pengubahan program. Kurangnya tenaga pengajar dalam pelaksanaan kegiatan ekstrakurikuler sains club di SD My Little Island merupakan hambatan yang harus segera ditangani, hal ini dapat mengakibatkan terganggunya kegiatan karena faktor yang terpenting dari kegiatan ini terletak dari tenaga pengajarnya. Kegiatan ekstrakurikuler sains club di SD My Little Island memiliki peminat yang cukup banyak sehingga ketika diadakan pendaftaran peserta pada awal semester sangat banyak yang ingin mengikuti kegiatan ini, dilain hal kegiatan ini juga memiliki batas penerimaan peserta didik yang akhirnya ketika terjadi kelebihan pendaftar harus disalurkan ke kegiatan ekstrakurikuler yang lain sesuai dengan pilihan kedua yang telah dipilih oleh peserta didik. Pembina kegiatan ekstrakurikuler sains club ditentukan oleh Lembaga Sains Cendikia berdasarkan dengan rekomendasi yang diberikan oleh sekolah. Pembina kegiatan ekstrakurikuler sains club di SD My Little Island berjumlah dua orang, hal ini dirasa kurang dan menjadi hambatan karena peserta didik yang memiliki karakteristik berbeda sedangkan pembina kegiatan yang juga memiliki keterbatasan dalam berbahasa selain Bahasa Indonesia dan Bahasa Inggris.

Pengubahan waktu menjadi hambatan dalam pelaksanaan kegiatan ini dikarenakan ketika kegiatan yang seharusnya berlangsung dan harus diliburkan karena sesuatu hal, maka juga akan merubah susunan program yang telah dibuat. Jika sekolah ingin mengganti waktu pelaksanaan, maka Lembaga Sains Cendikia harus menata ulang jadwal mengajar pembina kegiatan ekstrakurikuler sesuai dengan keinginan sekolah untuk mengganti waktu yang telah diubah. Sesuai dengan teori Ubaidah (2012) yang menyatakan bahwa penjadwalan merupakan salah satu kegiatan administrasi di sekolah. Jadwal yang dimaksudkan untuk mengatur program belajar, praktik, program lapangan dapat terselenggara secara tertib sesuai dengan ketentuan yang berlaku dengan memanfaatkan seluruh sumber daya yang tersedia dengan segala keterbatasan.

Perubahan program merupakan hambatan dalam pelaksanaan kegiatan ekstrakurikuler sains club, hal ini dikarenakan program yang telah disusun dan diajukan ke sekolah terkadang mendapatkan masukan dan harus diubah sesuai dengan kondisi dan keinginan sekolah. Pengubahan program harus disesuaikan dengan inovasi yang sedang berkembang sehingga kegiatan ini tidak tertinggal dengan kegiatan lain yang lebih memanfaatkan keunggulan digital atau IPTEK. 


\section{Faktor Pendukung Pelaksanaan Kegiatan Ekstrakurikuler Sains Club untuk Meningkatkan Keaktifan Peserta Didik dalam Pembelajaran Science di SD My Little Island}

Faktor pendukung dalam pelaksanaan kegiatan ekstrakurikuler sains club meliputi terpenuhinya sarana dan dukungan yang diberikan oleh sekolah. Sarana yang dibutuhkan setiap pertemuannya adalah alat dan bahan dalam melakukan eksperimen, alat dan bahan ini dipersiapkan oleh Lembaga Sains Cendikia berdasarkan tema yang akan dilaksanakan. Sarana yang telah tersedia membantu dalam pelaksanaan kegiatan, hal ini dikarenakan semua eksperimen menggunakan alat dan bahan yang terkadang peserta didik tidak memilikinya. Sehingga, eksperimen atau percobaan dapat berjalan dengan baik sesuai dengan langkah-langkah yang tertulis di modul. Faktor pentingnya terpenuhi sarana ini dijelaskan dalam Ubaidah (2012) yang menjelaskan bahwa sarana pendidikan terbagi menjadi alat pelajaran, alat peraga dan media pembelajaran. Sarana dan prasarana merupakan salah satu faktor yang penting dalam penyelenggaraan Kegiatan Ekstrakurikuler Sains Club, karena apabila sarana yang digunakan kurang mendukung maka penyelenggaraan kegiatan kurang maksimal.

Dukungan dari sekolah mengenai adanya kegiatan ekstrakurikuler sains club sangat diperlukan untuk meningkatkan eksistensi dan membuat kegiatan lebih banyak diminati oleh peserta didik. Sekolah memberikan tugas tambahan kepada guru untuk menjadi penanggungjawab kegiatan. Penanggungjawab kegiatan ini bertugas membantu Pembina kegiatan ekstrakurikuler sains Club dalam pelaksanaannya, serta melakukan pengawasan terhadap jalannya kegiatan dari awal hingga akhir. Pembina kegiatan merasakan sangat terbantu dengan adanya Penanggungjawab kegiatan ekstrakurikuler sains club karena banyaknya peserta didik yang mengikuti sehingga Pembina kegiatan merasa kewalahan dalam mengelola kelas ketika kegiatan berlangsung. Hal ini sesuai dengan ungkapan Mustiningsih (2018) yang menjelaskan bahwa pihak-pihak dari satuan pendidikan bersama-sama mewujudkan keunggulan dalam ragam kegiatan ekstrakurikuler sesuai dengan sumber daya yang dimiliki.

\section{Upaya Mengatasi Hambatan dari Kegiatan Ekstrakurikuler Sains Club untuk Meningkatkan Keaktifan Peserta Didik dalam Pembelajaran Science di SD My Little Island}

Suatu kegiatan tidak terlepas dari hambatan, akan tetapi setiap hambatan pasti memiliki solusi atau alternative dalam menanggulanginya. Pada pembahasan kali ini akan membahas mengenai upaya dalam mengatasi hambatan dari kegiatan ekstrakurikuler sains club di SD My Little Island. Upaya untuk mengatasi hambatan dari kurangnya tenaga pengajar dalam kegiatan ini yaitu dengan sekolah memberikan tugas tambahan kepada guru sebagai penanggungjawab kegiatan ekstrakurikuler sains club. Penanggungjawab kegiatan ini bertugas untuk mengawasi pelaksanaan kegiatan ekstrakurikuler sains club dan membantu ketika pembina kegiatan ekstrakurikuler mengalami kesulitan. Hal ini sesuai dengan pendapat dari Mustiningsih (2018) mengenai keterlibatan satuan pendidikan yaitu tenaga kependidikan dan pembina ekstrakurikuler bersama-sama mewujudkan keunggulan dalam kegiatan ekstrakurikuler. Hambatan lain yang berasal dari peserta didik yaitu perbedaan karakeristik peserta didik, yaitu dalam hal keinginan, kesukaan, atau sesuatu yang ingin dicapai. Hal ini dapat diatasi dengan cara penyusunan program sesuai keinginan peserta didik yaitu dengan memeberikan kelonggaran kepada peserta didik mengenai program atau tema yang akan diikuti. Selain itu, program yang dibuat disesuaikan dengan keinginan peserta didik yaitu dengan memasukkan unsur benda cair, padat, gas dalam setiap percobaan. Permasalahan lain yang timbul adalah dari kegiatan ekstrakurikuler sains club adalah tidak tersediannya ruangan laboratorium IPA, hal ini dapat diatasi dengan memanfaatkan ruang kelas yang kosong sebagai tempat melakukan praktik dan eksperimen.

Pengubahan jadwal pelaksanaan dan pengubahan program kegiatan merupakan hambatan yang tidak dapat dihindari, karena dalam kegiatan ini terdapat dua lembaga yang melakukan kerjasama yaitu SD My Little Island dengan Lembaga Sains Cendikia. Namun, hambatan ini dapat diatasi dengan pergeseran waktu dan penyesuaian program sesuai dengan inovasi. Waktu yang diubah harus disesuaikan dengan program yang telah ditetapkan dan disepakati, dan menyesuaikan pula dengan jadwal dari pembina kegiatan ekstrakurikuler. 
Ilmu Pengetahuan Alam menurut Sumaji (2009) memiliki upaya membangkitkan minat manusia agar mau meningkatkan kecerdasan dan pemahamannya tentang alam seisinya yang terkadang belum diketahui oleh kebanyakan orang. Perkembangan yang semakin pesat, membuktikan bahwa teknologi juga memiliki peran dalam kegiatan yang berinteraksi langsung dalam lingkungan, hal ini mengakibatkan kemampuan Sumber Daya Manusia (SDM) juga akan meningkat. Hal ini sesuai dengan upaya yang dilakukan oleh sekolah dalam mengatasi hambatan yang ada yaitu dengan menyesuaikan program sesuai dengan inovasi seperti belajar sambil bermain, melakukan kegiatan yang belum pernah dilakukan sebelumnya serta membuat alat dan bahan semenarik mungkin untuk meningkatkan antusiasme peserta didik.

\section{SIMPULAN}

Bedasarkan hasil penelitian dapat disimpulkan: (1) perencanaan kegiatan ekstrakurikuler sains club di SD My Little Island dilakukan setiap awal semester. Kegiatan yang dilakukan dalam perencanaan meliputi penetapan tujuan kegiatan, penetapan indikator kegiatan, penyusunan program kegiatan, menentukan pihak-pihak yang terlibat atau berperan dalam kegiatan perencanaan baik dari Lembaga Sains Cendikia atau dari SD My Little Island, penyusunan alokasi dana untuk kegiatan ekstrakurikuler sains club, memenuhi sarana dan prasarana untuk pelaksanaan kegiatan, menetapkan tata tertib kegiatan, serta menentukan alokasi waktu untuk pelaksanaan kegiatan, (2) Pengorganisasian dalam kegiatan ekstrakurikuler sains club meliputi penyusunan struktur organisasi, penentuan waktu pembuatan struktur organisasi, dan pembagian tugas dan wewenang, (3) pelaksanaan kegiatan ekstrakurikuler sains club di SD My Little Island yang meliputi, penyesuaian program dengan jadwal pelaksanaan, implementasi program, peran serta pihak sekolah dan lembaga dalam pelaksanaan, peningkatan antusiasme peserta didik, peningkatan keaktifan peserta didik, (4) Penilaian dalam kegiatan ini meliputi menyusun dan menentukan kriteria keberhasilan program, melakukan pengawasan terhadap kegiatan ekstrakurikuler sains club, melakukan penilaian kegiatan, membuat laporan hasil pengawasan, dan melakukan evaluasi, (5) Faktor penghambat yang terdapat dalam kegiatan ekstrakurikuler sains club meliputi kurangnya tenaga pengajar, perbedaan karakteristik peserta didik, tidak ada ruang laboratorium IPA untuk melakukan eksperimen, pengubahan jadwal kegiatan, serta pengubahan program kegiatan, (6) Faktor pendukung dari kegiatan ini meliputi penugasan guru sebagai penanggungjawab kegiatan di kelas, terpenuhinya sarana untuk melakukan eksperimen, (7) upaya untuk mengatasi hambatan dalam kegiatan ekstrakurikuler ini meliputi, penugasan guru oleh sekolah untuk membantu dalam pelaksanaan, menyusun program sesuai dengan keinginan peserta didik agar kegiatan yang dilakukan dapat merata, memanfaatkan ruang kelas sebagai ruang praktik, pergeseran waktu pelaksanaan menjadi lebih cepat atau lambat agar tidak mengubah waktu dan program yang telah disusun, serta penyesuaian program dengan inovasi agar kegiatan tidak monoton dan membosankan.

\section{DAFTAR RUJUKAN}

Aini, S. (2017). Pengaruh Kedisiplinan Guru Terhadap Karakter Siswa Dalam Belajar di Tsanawiyah AL-Washliyah Ismailiyah No 82. Medan, (Online), (http://repository.uinsu.ac.id/2747/1/Skripsi\%20SYARIFAH\%20AINI. pdf), diakses 10 Februari 2018.

Andani, R.T. (2016). Perbedaan Motivasi danisiplin Kerja Pada Guru PNS dan Bukan PNS di SMP Negeri seSurabaya Barat. (Online), (http://jurnalmahasiswa.unesa.ac.id/index.php/inspirasi-manajemen-pendidikan/ article/download/14610/13260), di akses 28 Mei 2019.

Anggraeni,A.L. (2017). Analisis Perbedaan Tingkat Disiplin Kerja PNS Sebelum dan Sesudah Implementasi Peraturan Bupati Nomor 11 Tahun 2015, (Online), (http://repository.usd.ac.id/13193/2/132214084_full.pdf), diakses 15 April 2019.

Arifin, I., Juharyanto, Mustiningsih, \& Taufiq, A. (2018). Islamic Crash Course as a Leadership Strategy of School Principals in Strengthening School Organizational Culture. SAGE Open, 8(3), 215824401879984. https://doi. org/10.1177/2158244018799849. 
Ayu, P.M, Buchari.N, \& Isnaini. (2018). Faktor-Faktor Yang Mempengaruhi Kedisiplinan Guru Di Smp Negeri 3 Mapat Tunggul Selatan Kabupaten Pasaman. (Online), (http://jim.stkip-pgri-sumbar.ac.id/jurnal/ download/7321\&sa), diakses 22 Mei 2019.

Banawi \& Arifin, M. (2012). Etika dan Profesi Kependidikan. Jogyakarta: Ar-Ruzz Media.

Damanik, Saipul, Ambri. (2014). Pramuka Ekstrakurikuler Wajib di Sekolah. (Online), (https://jurnal.unimed. ac.id/2012/index.php/JIK/article/view/6090), diakses 15 Juli 2019.

Hasibuan, M.S.P. (1994). Manajemen Sumber Daya Manusia, Dasar dan Kunci Keberhasilan. Jakarta: CV. Haji Masagung.

Helmi, A. F. (1996). Disiplin Kerja. (Online), (http:// http://avin.staff.ugm.ac.id/data/jurnal/disiplinkerja_avin. pdf), diakses 10 Februari 2018.

Juharyanto. (2017a). Kepemimpinan unggul Kepala Sekolah Dasar Daerah Terpencil (Studi Multisitus pada Sekolah Dasar di Kabupaten Bondowoso). Jurnal Sekolah Dasar, 1 (Tahun 26), 89-100. http://jurnal.fip. um.ac.id/sekolahdasar.

Juharyanto, J. (2017b). Implementation of Principal Personality Competency as a Change Agent on School Achievement in Remote Area One Roof School. Proceedings of the 2nd International Conference on Educational Management and Administration (CoEMA 2017), (October). https://doi.org/10.2991/coema-17.2017.7.

Kusumawati, D.K. (2006) Hubungan antara persepsi terhadap kepemimpinan transformasional dengan motivasi mengembangkan karir (Skripsi tidak diterbitkan) Fakultas Psikologi Universitas Gadjah Mada Yogyakarta, Yogyakarta, Indonesia.

Nastiti, S.M. (2016). Perbedaan Kinerja Guru Berdasarkan Status Kepegawaian PNS dan Non PNS Di SMA Negeri Se Kabupaten Rembang. (Online), (https://lib.unnes.ac.id/29068/1/3401412144.pdf), di akses 15 Februari 2018.

Pratiwi N,A. (2015). Studi komparasi disiplin kerja guru sekolah dasar negeri yang belum dan sudah bersertifikasi di wilayah kecamatan Tapung Hulu Kampar, Hanata widya, 4, (3).

Prijodarminto, S. (1993). Disiplin Kiat Menuju Sukses. Jakarta: PT Pradnya Pramita cetakan kedua.

Rahayu,D, dkk. (2014). Kepemimpinan Kepala Sekolah Dan Kedisiplinan Guru SMPN Kota Surakarta. (Online), (https://media.neliti.com/media/publications/112221-ID-kepemimpinan-kepala-sekolah-dan-kedisiplinan. pdf\&sa), di akses 22 Mei 2019.

Sa'adah.N, I M. Yudana \& I G K Arya Sunu. (2018). Studi Komparatif Tentang Perbedaan Kinerja Guru Pkn Pns Dengan Non Pns (Studi Pada Smp Di Kota Singaraja), (Online), (https://ejournal.undiksha.ac.id/index.php/ JJPP/article/download/15088/9235), di akses 22 Mei 2019.

Ubaidah, Siti. (2012). Manajemen Ekstrakurikuler dalam Meningkatkan Mutu Sekolah. (Online), (https://media. neliti.com/media/publications/56738-ID-manajemen-ekstrakurikuler-dalam-meningka.pdf), diakses 26 Juni 2019.

Unaradjan,D. (2003). Manajemen Disiplin. Jakarta: PT Gramedia.

Wijaya,A. (2018). Perbedaan yang Signifikan antara Sekolah Negeri dan Sekolah Swasta. (Online), (https:// id.quora.com/Apa-perbedaan-yang-signifikan-antara-sekolah-negeri-dan-sekolah-swasta), di akses 20 Maret 2019. 